\title{
Canopy-forming species mediate the effects of disturbance on macroalgal assemblages on Portuguese rocky shores
}

\author{
Iacopo Bertocci ${ }^{1, *}$, Francisco Arenas ${ }^{1}$, Miguel Matias ${ }^{1,2}$, Stefano Vaselli ${ }^{1}$, \\ Rita Araújo ${ }^{1}$, Helena Abreu ${ }^{1}$, Rui Pereira ${ }^{1}$, Raquel Vieira ${ }^{1}$, Isabel Sousa-Pinto ${ }^{1,3}$ \\ ${ }^{1}$ CIIMAR, Centro Interdisciplinar de Investigação Marinha e Ambiental, Rua dos Bragas, 289, 4050-123, Porto, Portugal \\ ${ }^{2}$ Centre for Research on Ecological Impacts of Coastal Cities, Marine Ecology Lab A11, School of Biological Sciences, \\ The University of Sydney, New South Wales 2006, Australia \\ ${ }^{3}$ Department of Botany, Faculty of Sciences, University of Porto, Rua do Campo Alegre, 1191, 4150-181, Porto, Portugal
}

\begin{abstract}
Understanding the relationship between biodiversity and stability is a central issue in ecology. This is particularly needed under current scenarios of biodiversity loss due to multiple anthropogenic stressors. In this study, we experimentally examined the combined effects of the loss of key functional species (canopy-forming macroalgae) and mechanical disturbance on macroalgal intertidal assemblages at 2 sites along the rocky coast of northern Portugal. We tested the model that the canopy may buffer the effects of disturbance on associated organisms, leading to the logical hypothesis that effects of mechanical disturbance would be lower where the canopy was left intact compared to patches where it was experimentally removed. The proposed model was supported by multivariate and univariate results, as both differences in the structure of whole assemblages and in the abundance of individual taxa between disturbed and undisturbed assemblages were reduced or prevented by the presence of the canopy, independently of the examined site. Specifically, only in the absence of the canopy did disturbance determine a decrease in the abundance of the red alga Ahnfeltiopsis devoniensis and an increase in articulated coralline algae of the genus Corallina. Present findings have relevant implications for understanding and predicting the consequences of multiple factors responsible for the erosion of biodiversity occurring globally in coastal areas, as current rates of loss of canopy-forming species in urban areas may be expected to exacerbate the effects of predicted climate change, including modifications in intensity and temporal patterns of storms.
\end{abstract}

KEY WORDS: Biodiversity · Multiple stressors $\cdot$ Canopy algae $\cdot$ Disturbance $\cdot$ Rocky intertidal Resale or republication not permitted without written consent of the publisher

\section{INTRODUCTION}

Understanding the relationship between changes in biodiversity and ecosystem properties such as stability, nutrient and energy fluxes, or productivity is of increasing concern for ecology, policy makers, and the general public (Vitousek 1994, Costanza et al. 1997, Chapin et al. 1998, Hooper et al. 2005).

Theoretical and experimental research has documented strong links between diversity and stability, often with a direct relationship between diversity and resistance and resilience of communities (Pimm 1984, McCann 2000, Ives \& Carpenter 2007, Griffin et al. 2009). However, to date, most research has been conducted in terrestrial systems (Hooper \& Vitousek 1997, Tilman 1999, Hooper et al. 2005, van Ruijven \& Berendse 2010), and relatively few examples of empirical marine studies are available (Stachowicz et al. 2007, Boyer et al. 2009). Additionally, most marine studies examining the diversity-stability hypothesis were carried out in the context of biological invasions, with few attempts to evaluate how diversity shapes the 
ability of communities to resist perturbations. These include specific studies on macroalgal beds and thermal stress (Allison 2004), eelgrass meadows and grazing by geese (Hughes \& Stachowicz 2004) or disturbance (Williams 2001, Reusch et al. 2005), and microalgal biomass and combinations of sediment types and varying temperatures (Worm et al. 2006). The ability of systems dominated by canopy-forming algae to resist disturbance needs further experimental evaluation. Moreover, changes in patterns of biodiversity, and their functional consequences, are affected by multiple biological and abiotic drivers (Paine et al. 1998, Halpern et al. 2008), leading to the need for examining how the effects of one stressor are modulated by those of concomitant others (Folt et al. 1999, Crain et al. 2008).

Species with particular morphological or physiological traits, whose extinction may have drastic consequences for relevant ecological processes, are of overwhelming importance for the study of the relationship between biodiversity and ecosystem functioning (Schwartz et al. 2000, Geider et al. 2001, Loreau et al. 2002, Smith \& Knapp 2003). Such species include key habitat formers (ecosystem engineers, sensu Jones et al. 1994) occurring at different locations (Jenkins et al. 1999, Benedetti-Cecchi et al. 2001, Eriksson et al. 2006, 2007). These species modify the spatial complexity and provide a specific habitat for a number of organisms, so that their removal may cause drastic changes in the structure of associated assemblages, as it was documented for canopy-forming macroalgae (Benedetti-Cecchi et al. 2001, Schiel \& Lilley 2007), seagrasses (Ramage \& Schiel 1999), and mussel beds (Seed 1996). Mechanisms responsible for such effects include modifications of light, temperature, local hydrodynamics, sedimentation, and competition for the substratum (Reed \& Foster 1984, Duggins et al. 1990, McCook \& Chapman 1991, Seed 1996), factors that can affect the associated assemblages both positively, for example by ameliorating physical conditions, and negatively, for example by monopolizing space (Bertness et al. 1999, Bulleri et al. 2002). These characteristics make algal canopies a key functional element of coastal habitats, in terms of production, cycling of nutrients, and food webs (Underwood 1998, 1999). There is evidence that algal canopies are particularly sensitive to anthropogenic disturbance and tend to decline globally in urban areas (Benedetti-Cecchi et al. 2001, Airoldi \& Beck 2007, Connell et al. 2008, Mangialajo et al. 2008). Moreover, particularly in intertidal habitats, they are extremely exposed to multiple stressors, such as human trampling (Schiel \& Taylor 1999, Araújo et al. 2009a), burial, and sediment scouring (Schiel et al. 2006) and to climate change (Thompson et al. 2002).
In intertidal habitats, mechanical disturbance due to intense storms may remove patches of algal canopies (Underwood 1998), with the consequent local extinction of understory species (Dayton 1975, Bertness et al. 1999, Jenkins et al. 2004, Lilley \& Schiel 2006) and drastic direct and indirect effects on biological interactions (Underwood 1998, 1999). Furthermore, an increase in extreme storms is predicted by models of climate change (Emanuel 1987, Raper 1993, Michener et al. 1997, Easterling et al. 2000). Therefore, examining the relationship between the loss of algal canopies and physical disturbance is relevant to understanding and predicting the environmental impacts of humanrelated stressors on intertidal assemblages.

In this study, we experimentally examined the combined effects of the loss of canopy-forming macroalgal species and mechanical disturbance on macroalgal assemblages inhabiting the low rocky intertidal habitat of northern Portugal. The main hypothesis was that the presence of the canopy could buffer the effects of disturbance on the structure and diversity of understory assemblages and on patterns of abundance of individual algal organisms. Specifically, we tested the hypotheses that (1) mechanical disturbance would determine significant changes to assemblages and individual taxa where the canopy was experimentally removed, but not where it was left intact, (2) this pattern would be consistent between 2 sites located about $25 \mathrm{~km}$ apart along the Portuguese coast.

\section{MATERIALS AND METHODS}

Study site. The study was performed between January 2006 and April 2007 at 2 rocky sites, Viana do Castelo $\left(41^{\circ} 41^{\prime} \mathrm{N}, 08^{\circ} 51^{\prime} \mathrm{W}\right)$ and Amorosa $\left(41^{\circ} 38^{\prime} \mathrm{N}\right.$, $08^{\circ} 49^{\prime} \mathrm{W}$ ), along the coast of northern Portugal, at lowtide level (between 0.5 and $1 \mathrm{~m}$ above Chart Datum (LAT)). This temporal scale is in most cases appropriate for detecting direct and indirect effects of the examined processes on intertidal assemblages (Menge 1997, Strong 1997, Benedetti-Cecchi et al. 2001). The tidal regime along the Portuguese coast is semidiurnal, with maximum spring tides of 3.5 to $4 \mathrm{~m}$. The typical rocky shore is granitic, and the coast is exposed to prevailing northwest oceanic swells that are particularly intense during the winter (Araújo et al. 2005). With the exception of the most exposed sites, which are generally dominated by mussels Mytilus galloprovincialis Lamarck and encrusting algae, such as Lithophyllum incrustans Philippi, this level on the shore is characterized by highly diversified macroalgal assemblages. These are dominated by small canopy-forming species, such as the red algae Mastocarpus stellatus (Stackhouse) Guiry, Chondrus crispus Stackhouse, and 
Gigartina pistillata (S.G. Gmelin) Stackhouse. Understory assemblages include turf-forming species, such as the red algae Chondracanthus acicularis (Roth) Fredericq, Ahnfeltiopsis devoniensis (Greville) P.C. Silva \& DeCew, Gymnogongrus crenulatus (Turner) J. Agardh, the articulated coralline algae of the genus Corallina, and the brown algae Bifurcaria bifurcata R. Ross and Himanthalia elongata (Linnaeus) S.F. Gray. Large kelps, such as Saccorhiza polyschides (Lightfoot) Batters, Laminaria ochroleuca Bachelot de la Pylaie and L. hyperborea (Gunnerus) Foslie, are sparse at this height on the shore, being more abundant in the subtidal habitat and in rock pools, and were never found in experimental units. The most common grazing invertebrates are limpets (Patella spp.) and trochids of the genus Gibbula (Araújo et al. 2005, 2009b).

Experimental design and sampling. A total of 20 patches $(30 \times 30 \mathrm{~cm}$, from tens of $\mathrm{cm}$ to a few meters apart) with a cover of algal canopy (mixtures of Mastocarpus stellatus, Chondrus crispus, and Gigartina pistillata) $>70 \%$ and 10 to $15 \mathrm{~cm}$ thick were identified at each site at the beginning of the study (January 2006) and marked with screws at the corners for subsequent relocation. This patch size was comparable to that of disturbed patches identified in a previous study in the same geographic area (Viejo et al. 2008). Since the 3 canopy-forming species were comparable in size, they likely had comparable abilities to create an understory habitat. We therefore assumed that the effects of the algal canopy manipulated in the present study were not affected by potential differences in the relative abundance of each species in patches assigned to each experimental treatment. Five patches were randomly assigned to each of the following treatments: canopy intact and undisturbed $(+\mathrm{C},-\mathrm{D})$, canopy intact and disturbed $\left(+\mathrm{C}_{1}+\mathrm{D}\right)$, canopy removed and undisturbed $(-\mathrm{C},-\mathrm{D})$, and canopy removed and disturbed $\left(-C_{1}+\mathrm{D}\right)$. The experimental removal of the canopy from the whole area of $10-\mathrm{C}$ patches was done using a knife, taking care to leave the understory organisms undamaged. In patches assigned to the $+D$ treatment, a mechanical disturbance was applied using a hand rake and scratching the rock surface in 2 orthogonal directions, a procedure able to create patches of bare space, interspersed within intact assemblages, in a range of sizes comparable to that documented for other rocky intertidal systems (Benedetti-Cecchi \& Cinelli 1994). This treatment followed the removal of the canopy in $-\mathrm{C},+\mathrm{D}$ treatment, while it was applied on intact assemblages in the $+\mathrm{C}_{1}+\mathrm{D}$ treatment. In this last treatment, therefore, some individuals of canopy-forming species could have been removed or damaged by experimental disturbance. However, this effect was analogous to that of any mechanical disturbance naturally impacting the studied assemblages, and we logi- cally assumed that this could not prevent our experimental treatments from testing the proposed model of a buffering effect of the canopy on disturbance. Half of the number of the scratches necessary, on average, to remove all biomass from the substratum, as shown by a pilot study, was established as the standard intensity of disturbance. In order to maintain the temporal scale of our treatments comparable to that of canopy loss and mechanical disturbance occurring naturally on the shore, the removal of the canopy was maintained throughout the study, by periodically removing the individuals of the canopy-forming species that recruited in experimental patches assigned to $-\mathrm{C}$ treatments, while disturbance was applied only once at the beginning of the experiment.

At each site, algal organisms were sampled visually at the beginning (January 2006, immediately before the start of the experiment) and at 5 dates over the period of the study (January 2006, April 2006, September 2006, February 2007, April 2007) by using a quadrat of $30 \times 30 \mathrm{~cm}$ divided into 25 sub-quadrats of $6 \times 6 \mathrm{~cm}$. Given the size of the examined organisms and the small scales of variability documented for intertidal algal and invertebrate assemblages (Benedetti-Cecchi 2001, Fraschetti et al. 2005), the size of patches was considered appropriate to obtain representative estimates of abundance (Andrew \& Mapstone 1987). Cover values were calculated by assigning each taxon in each sub-quadrat a value between 0 (absence of the taxon) and 4 (whole subquadrat covered) and expressing final values as percentages (Dethier et al. 1993). Organisms were identified to the most detailed level of taxonomic resolution achievable in the field, in some cases lumping different species into the same genus.

Analysis of data. Before performing experimental treatments, we assessed whether assemblages in experimental patches established at each site were similar, as initial differences might have affected their responses to experimental treatments. Not yet treated assemblages were compared through multivariate analysis of variance based on permutations (PERMANOVA, Anderson 2001), including 2 fixed and crossed factors, Canopy and Disturbance, and 5 replicates (the 5 patches assigned to each factorial combination of treatments), separately for each site.

To assess the effectiveness of experimental treatments, the percentage cover of the canopy over the period of the study (i.e. averaged over 5 dates of sampling) and that of bare rock at the first date of sampling were measured, separately for each site. In $+C$ treatments, estimating the cover of bare rock in some cases required moving aside the canopy to make the understory habitat visible, analogously to sampling of associated assemblages at each time. 
Separate and interactive effects of experimental treatments were tested on the whole assemblage and on individual taxa. Multivariate responses were examined by comparing disturbed and undisturbed assemblages in patches where the canopy was left untouched and in patches where it was removed over the course of the study. This was made by calculating centroids for assemblages sampled at each site in each of the 5 patches assigned to each combination of experimental treatments across the 5 sampling dates. Separate analyses of data from each sampling date were not performed in order to avoid the uncontrolled increase of the probability of Type I error occurring when repeating tests on data that are not temporally independent (Underwood 1997), such as in the present case. Since the average of raw abundance data of individual taxa is not an appropriate measure of the average assemblage across time (Legendre \& Anderson 1999, McArdle \& Anderson 2001), we first calculated principal coordinates (Gower 1966) from a Bray-Curtis dissimilarity matrix (Bray \& Curtis 1957) among the full set of data, in order to place the observations into a Euclidean space, without affecting the Bray-Curtis measure (i.e. the distance between any pair of observations based on principal coordinates is equivalent to the dissimilarity between those observations obtained from the original data). Centroids were calculated as arithmetic averages of the principal coordinates over the 5 sampling dates (McArdle \& Anderson 2001) using the computer program PCO (Anderson 2003). A matrix of Euclidean distances between each pair of centroids was then calculated, separately for each site. To provide a direct comparison of undisturbed and disturbed assemblages relatively to the presence or the removal of the canopy, we calculated Euclidean distances between 5 undisturbed assemblages paired at random with 5 disturbed assemblages, separately for $+C$ and $-C$ treatments. These distances were finally analyzed with a 2-way analysis of variance (ANOVA), including the crossed factors Site (random, 2 levels, Viana versus Amorosa) and Canopy (fixed, 2 levels, + C versus $-C$ ). A lower distance (corresponding to a larger similarity) between undisturbed and disturbed assemblages where the canopy was left intact compared to patches where it was removed was expected in order to support a buffering effect of the canopy on mechanical disturbance.

ANOVA was also used to examine responses of the total number of taxa (a surrogate measure of species richness) and the cover of the most abundant individual taxa over the period of the study. This was made by calculating average values of each response variable over 5 sampling dates, then analyzing them with a 3way model, including the same 2 factors (Site and Canopy) as the multivariate analysis, crossed with Disturbance (fixed, 2 levels, +D versus -D).
When necessary, data were log-transformed to meet the assumption of homogeneity of variances (after Cochran's test). SNK tests were used for a posteriori comparisons of means $(\alpha=0.05)$.

\section{RESULTS}

PERMANOVA indicated that assemblages in patches assigned to each experimental treatment did not differ at the beginning of the study at both sites (Viana: $\mathrm{MS}_{\mathrm{CANOPY}}=698.77$, pseudo- $F=0.31, \mathrm{p}=0.829$; $\mathrm{MS}_{\text {DISTURBANCE }}=493.05$, pseudo- $F=0.22, \mathrm{p}=0.911$; $\mathrm{MS}_{\mathrm{CANOPY} \times \text { DISTURBANCE }}=1387.73$, pseudo- $F=0.61, \mathrm{p}=$ 0.577; Amorosa: $\mathrm{MS}_{\mathrm{CANOPY}}=485.57$, pseudo- $F=1.37$, $\mathrm{p}=0.188 ; \mathrm{MS}_{\text {DISTURBANCE }}=315.10$, pseudo- $F=0.89, \mathrm{p}=$ $0.552 ; \mathrm{MS}_{\text {CANOPY } \times \text { DISTURBANCE }}=354.75$, pseudo $-F=1.00$, $\mathrm{p}=0.434)$.

Canopy cover averaged over 5 sampling dates was around 60 to $70 \%$ in $+\mathrm{C}$ treatments, while in $-\mathrm{C}$ treatments it was always below 10\% (Fig. 1A). Disturbed
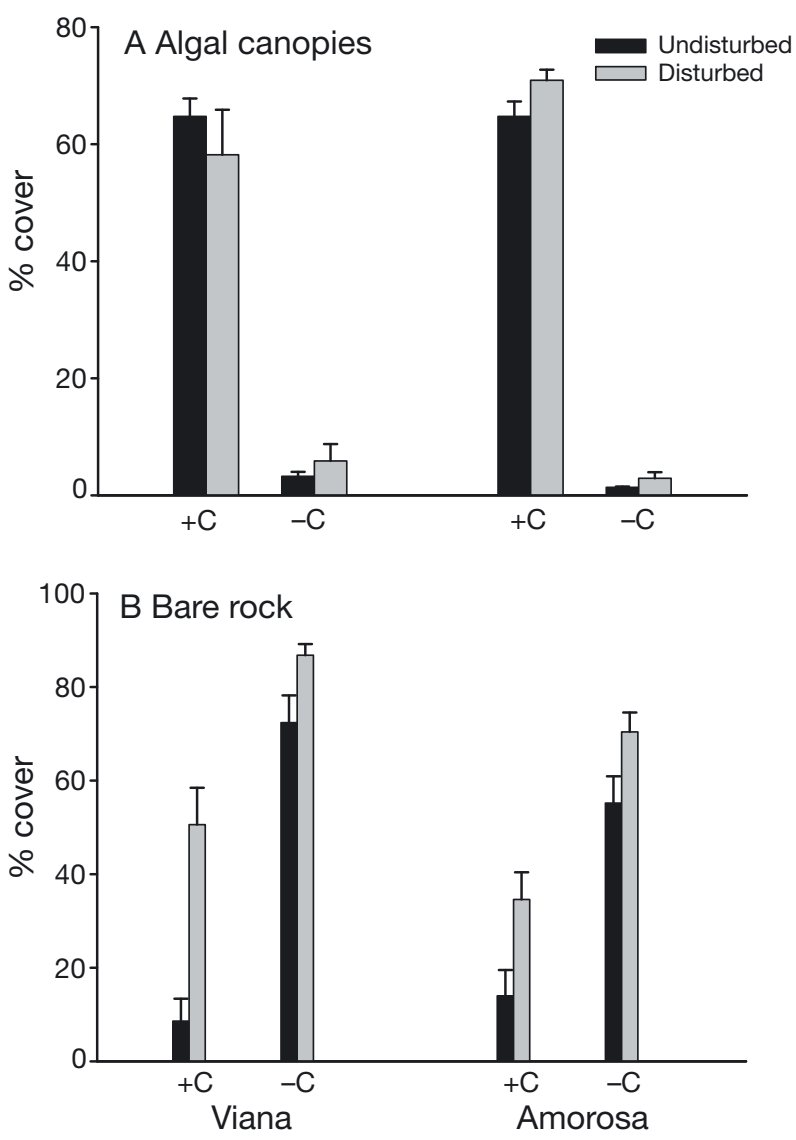

Fig. 1. Abundance of $(A)$ algal canopies (mean $+S E, n=25)$ over the period of the study and of $(B)$ bare rock $(+\mathrm{SE}, \mathrm{n}=5$ ) at the first date of sampling in patches assigned to each combination of experimental treatments $(+\mathrm{C}$ and $-\mathrm{C}$ indicate the presence or the experimental removal of the canopy, respectively), separately for each site 
Table 1. Analysis of variance examining the effects of site and algal canopies on the Euclidean distance between undisturbed and disturbed assemblages across 5 sampling dates. NS: not significant

\begin{tabular}{|lcccc|}
\hline Source of variation & df & MS & $F$ & $\mathrm{p}$ \\
\hline Site (S) & 1 & 0.34 & 0.01 & 0.912 \\
Canopy (C) & 1 & 483.99 & 490.32 & 0.028 \\
S $\times$ C & 1 & 0.99 & 0.04 & 0.851 \\
Residual & 16 & 27.07 & & \\
Cochran's $C$ test & $C=0.336, \mathrm{NS}$ & & & \\
Transformation & None & & & \\
\hline
\end{tabular}

treatments were characterized by larger proportion of bare rock compared to undisturbed treatments, although these differences were emphasized in patches where the canopy was left intact compared to those where it was experimentally removed (Fig. 1B). The absolute highest covers of bare rock were consistently displayed by $-\mathrm{C}$ treatments (Fig. 1B), likely as a direct consequence of the removal of canopy-forming species primarily attached to the substratum.

The effects of disturbance on the structure of whole assemblages were reduced by the presence of the canopy (Table 1). Specifically, disturbed and undisturbed assemblages were more similar, with values of

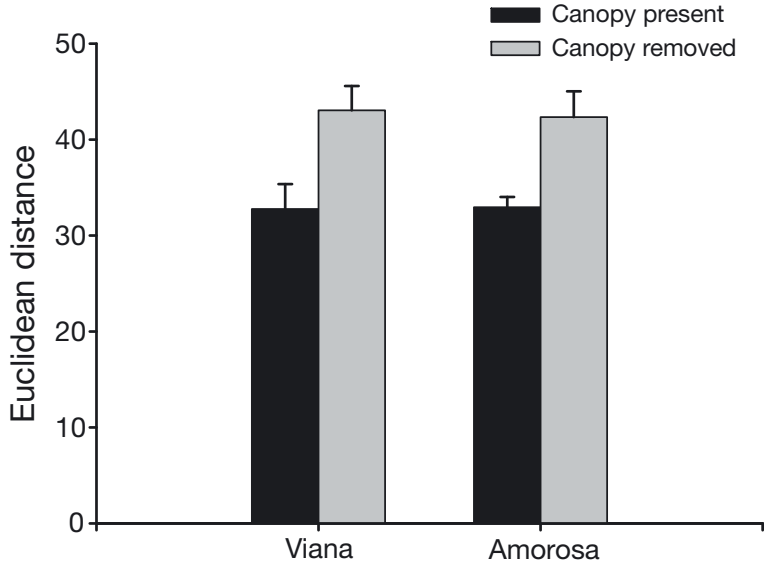

Fig. 2. Euclidean distance (mean $+\mathrm{SE}, \mathrm{n}=5$ ) between undisturbed and disturbed assemblages in patches where algal canopies were left intact or experimentally removed, separately for each site. Data averaged across 5 sampling dates

Euclidean distance about 35\% larger, in patches where the canopy was left untouched than in those where it was removed at both sites (Fig. 2).

The buffering effect of the canopy on disturbance was confirmed by responses of some individual taxa, such as Ahnfeltiopsis devoniensis and Corallina spp. (Table 2), although in taxon-specific directions. Inde-

Table 2. Analysis of variance examining the effects of site, algal canopies, and disturbance on the total number of taxa and the abundance of individual algal taxa across 5 sampling dates. NS: not significant

\begin{tabular}{|c|c|c|c|c|c|c|c|c|c|c|c|c|c|}
\hline \multirow[t]{2}{*}{$\begin{array}{l}\text { Source of } \\
\text { variation }\end{array}$} & \multicolumn{4}{|c|}{ Number of taxa } & \multicolumn{3}{|c|}{$\begin{array}{c}\text { Ahnfeltiopsiss } \\
\text { devoniensis }\end{array}$} & \multicolumn{3}{|c|}{ Calliblepharis jubata } & \multicolumn{3}{|c|}{$\begin{array}{c}\text { Chondracanthus } \\
\text { acicularis }\end{array}$} \\
\hline & df & MS & $F$ & $\mathrm{p}$ & MS & $F$ & $\mathrm{p}$ & MS & $F$ & $\mathrm{p}$ & MS & $F$ & $\mathrm{p}$ \\
\hline Site (S) & 1 & 13.9 & 4.2 & 0.561 & 0.4 & 2.3 & 0.136 & 17.5 & 35.2 & 0.000 & 0.0 & 0.0 & 0.863 \\
\hline Canopy (C) & 1 & 8.8 & 2.0 & 0.368 & 0.3 & 4.9 & 0.271 & 2.7 & 2.2 & 0.365 & 1.0 & 17.1 & 0.151 \\
\hline Disturbance (D) & 1 & 4.4 & 1089.0 & 0.019 & 0.0 & 0.8 & 0.542 & 0.2 & 46.9 & 0.084 & 1.3 & 89.1 & 0.067 \\
\hline $\mathrm{S} \times \mathrm{C}$ & 1 & 4.4 & 1.3 & 0.216 & 0.1 & 0.4 & 0.552 & 1.2 & 2.5 & 0.206 & 0.1 & 0.1 & 0.771 \\
\hline $\mathrm{S} \times \mathrm{D}$ & 1 & 0.0 & 0.0 & 0.926 & 0.0 & 0.2 & 0.656 & 0.0 & 0.0 & 0.918 & 0.0 & 0.0 & 0886 \\
\hline $\mathrm{C} \times \mathrm{D}$ & 1 & 0.5 & 0.3 & 0.633 & 14.5 & 136.3 & 0.049 & 0.0 & 0.3 & 0.663 & 1.2 & 1.5 & 0.437 \\
\hline $\mathrm{S} \times \mathrm{C} \times \mathrm{D}$ & 1 & 1.4 & 0.4 & 0.540 & 0.1 & 0.5 & 0.450 & 0.1 & 0.6 & 0.470 & 0.8 & 1.2 & 0.275 \\
\hline Residual & 32 & 3.3 & & & 0.2 & & & 0.2 & & & 0.7 & & \\
\hline Cochran's $C$ test & & $C=$ & $=0.276$, & NS & $C=$ & 0.186 & NS & $C=$ & 0.270 & NS & $C=$ & 0.256 & NS \\
\hline Transformation & & & None & & & $n(x+1$ & & & $\mathrm{n}(\mathrm{x}+1$ & & & $\mathrm{n}(\mathrm{x}+1$ & \\
\hline \multirow[t]{2}{*}{$\begin{array}{l}\text { Source of } \\
\text { variation }\end{array}$} & \multicolumn{4}{|c|}{ Corallina spp. } & \multicolumn{3}{|c|}{$\begin{array}{l}\text { Gymnogongrus } \\
\text { crenulatus }\end{array}$} & \multicolumn{3}{|c|}{ Stypocaulon scoparium } & \multicolumn{3}{|c|}{ Ulva spp. } \\
\hline & $\mathrm{df}$ & MS & $F$ & $\mathrm{p}$ & MS & $F$ & $\mathrm{p}$ & MS & $F$ & $\mathrm{p}$ & MS & $F$ & $\mathrm{p}$ \\
\hline Site $(\mathrm{S})$ & 1 & 0.5 & 2.5 & 0.221 & 3.1 & 8.8 & 0.006 & 52.4 & 6.6 & 0.015 & 2.9 & 16.3 & 0.000 \\
\hline Canopy (C) & 1 & 0.1 & 0.3 & 0.671 & 5.6 & 5.4 & 0.245 & 27.2 & 1.8 & 0.408 & 21.3 & 24.3 & 0.116 \\
\hline Disturbance (D) & 1 & 4.7 & 109.8 & 0.061 & 0.0 & 0.1 & 0.844 & 14.2 & 2.4 & 0.366 & 0.7 & 7.0 & 0.189 \\
\hline $\mathrm{S} \times \mathrm{C}$ & 1 & 0.2 & 1.1 & 0.305 & 1.0 & 2.9 & 0.084 & 15.1 & 1.9 & 0.179 & 0.9 & 4.9 & 0.068 \\
\hline $\mathrm{S} \times \mathrm{D}$ & 1 & 0.0 & 0.2 & 0.649 & 0.3 & 1.0 & 0.355 & 5.9 & 0.7 & 0.396 & 0.1 & 0.6 & 0.541 \\
\hline $\mathrm{C} \times \mathrm{D}$ & 1 & 2.7 & 394.4 & 0.032 & 0.0 & 0.0 & 0.801 & 22.2 & 1.9 & 0.397 & 0.1 & 2.9 & 0.431 \\
\hline $\mathrm{S} \times \mathrm{C} \times \mathrm{D}$ & 1 & 0.0 & 0.0 & 0.815 & 0.2 & 0.7 & 0.360 & 11.4 & 1.4 & 0.240 & 0.1 & 0.3 & 0.541 \\
\hline Residual & 32 & 0.2 & & & 0.4 & & & 8.0 & & & 0.2 & & \\
\hline Cochran's $C$ test & \multicolumn{4}{|c|}{$C=0.357, \mathrm{NS}$} & \multicolumn{3}{|c|}{$C=0.295, \mathrm{NS}$} & \multicolumn{3}{|c|}{$C=0.689,0.045$} & \multirow{2}{*}{\multicolumn{3}{|c|}{$\begin{array}{c}C=0.367, \mathrm{NS} \\
\operatorname{Ln}(x+1)\end{array}$}} \\
\hline Transformation & \multicolumn{4}{|c|}{$\operatorname{Ln}(x+1)$} & \multicolumn{3}{|c|}{$\operatorname{Ln}(x+1)$} & \multicolumn{3}{|c|}{ None } & & & \\
\hline
\end{tabular}


pendently of the site, the abundance of A. devoniensis was larger in undisturbed than in disturbed patches where the canopy was removed, while in $+C$ patches, disturbance did not exert any significant effect on this species (Fig. 3, $\mathrm{SNK}_{\mathrm{C} \times \mathrm{D}}=-\mathrm{C}:-\mathrm{D}>+\mathrm{D},+\mathrm{C}:+\mathrm{D}=-\mathrm{D}$, $\mathrm{SE}=0.103)$. An opposite pattern was displayed by Corallina spp., with larger abundance in $+\mathrm{D}$ than in $-\mathrm{D}$ patches combined with the removal of the canopy (Fig. 3, $\mathrm{SNK}_{\mathrm{C} \times \mathrm{D}}=-\mathrm{C}:+\mathrm{D}>-\mathrm{D},+\mathrm{C}:+\mathrm{D}=-\mathrm{D}, \mathrm{SE}=$ 0.100). Although not significant, a trend towards a negative response to disturbance only in $-\mathrm{C}$ patches was shown at both sites by Chondracanthus acicularis and the brown alga Stypocaulon scoparium (Table 2, Fig. 3).
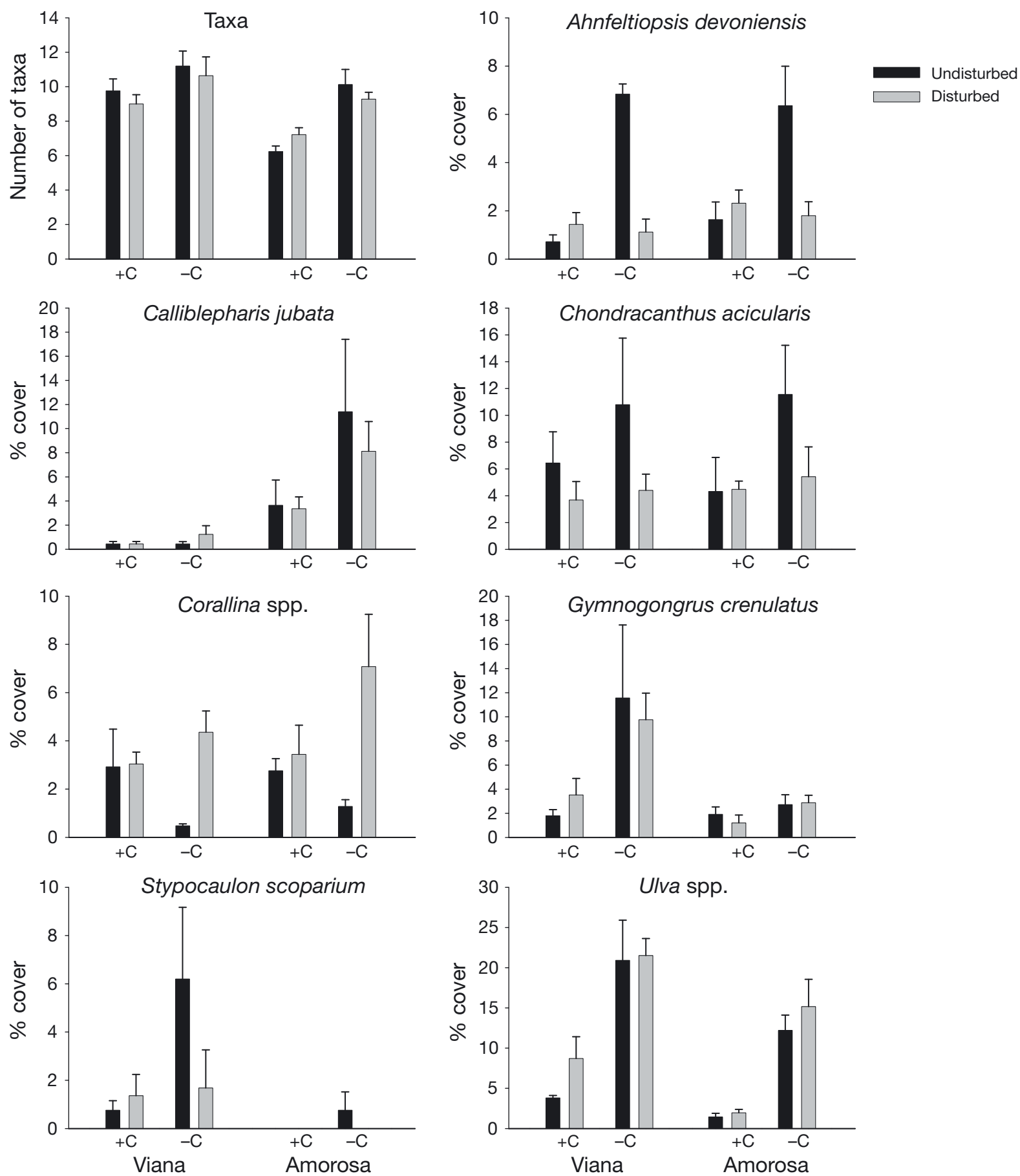

Fig. 3. Abundance of the total number of taxa and of individual taxa (mean $+\mathrm{SE}, \mathrm{n}=5$ ) in patches assigned to each combination of experimental treatments (abbreviations as in Fig. 1), separately for each site. Data averaged across 5 sampling dates 
No interactive effects of algal canopies and disturbance were observed for all other response variables examined (Table 2, Fig. 3). The total number of taxa was larger in $-D$ than in $+D$ patches independently of the site and the presence of the canopy (Table 2, Fig. 3). We also found some differences in local floras, independently of any effect of the manipulated factors: the red alga Calliblepharis jubata was more abundant at Amorosa than at Viana, while the opposite pattern was displayed by Gymnogongrus crenulatus and the green foliose algae Ulva spp. (Table 2, Fig. 3).

\section{DISCUSSION}

We hypothesized that algal canopies could buffer the effects of physical disturbance on intertidal algal assemblages and that this pattern was consistent between 2 sites along the coast of northern Portugal. These hypotheses were supported by our findings. The multivariate analysis showed that at both sites, undisturbed and disturbed assemblages were more similar in patches where the canopy was left untouched than in those where it was removed. Significant effects of disturbance only in the absence of the canopy were also documented for some of the individual algal taxa examined, such as Ahnfeltiopsis devoniensis, Corallina spp. and, less strongly, Chondracanthus acicularis and Stypocaulon scoparium, although with taxon-specific patterns.

It has been indicated that canopy-forming algae may mitigate the impact of stressing abiotic and biological factors on the associated assemblages through combinations of direct and indirect mechanisms (Bertness \& Leonard 1997, Jenkins et al. 1999, Schiel \& Lilley 2007). This model has been repeatedly invoked to explain the replacement of canopy-forming species by opportunistic turf-forming algae documented at several locations, particularly in urban areas (BenedettiCecchi et al. 2001, Bulleri et al. 2002, Mangialajo et al. 2008). In fact, harsher environmental conditions following the loss of the canopy may facilitate turfforming species over more sensitive species, as was indicated for beds of Hormosira banksii, where the removal of the canopy determined a drastic reduction of other fucoid algae and smaller branched algae unable to survive without the protective canopy layer (Lilley \& Schiel 2006). The larger abundance of turfforming algae in the genus Corallina in disturbed compared to undisturbed patches after the removal of the canopy documented in the present study could be explained according to such a mechanism, i.e. as a consequence of their greater ability to live under the most severe experimental conditions. An inverse relationship between the canopy cover and the abundance of coralline algae has been found in intertidal (Benedetti-Cecchi \& Cinelli 1992) and subtidal (Melville \& Connell 2001) habitats. Moreover, there is ample evidence that coralline algae tend to become dominant in sites subject to intense disturbance, including wave exposure (Bacchiocchi \& Airoldi 2003, Bulleri \& Airoldi 2005, Vaselli et al. 2008) and anthropogenic pressures (Airoldi et al. 1995, Boyra et al. 2004). The combination of reduced competition with other understory species more sensitive to the removal of the canopy and disturbance might explain the observed response of Corallina spp.

Direct effects of mechanical disturbance were likely responsible for the reduction of Ahnfeltiopsis devoniensis and, less strongly, Chondracanthus acicularis and Stypocaulon scoparium after the removal of the canopy. In particular, physical disturbance applied in the less protected habitat generated by the removal of the canopy might have negatively affected these species, analogously to what has been documented for other sources of mechanical stress, such as ice (McCook \& Chapman 1991) and sediment scouring (Connell 2003). Previous studies have indicated that these species tend to attain lower abundances on wave-exposed than on protected shores (Araújo et al. 2005, Tuya \& Haroun 2006).

Alternatively, but not mutually exclusively, the loss of canopies may drastically modify the responses of associated assemblages by altering trophic interactions. For instance, the removal of a canopy of Ascophyllum nodosum determined an increase in grazing intensity by limpets with consequent increase of barren areas (Jenkins et al. 1999, 2004), while the removal of Hormosira banksii was followed by a reduced abundance of whelks, leading to an increase in the abundance of their prey, i.e. barnacles (Underwood 1998, 1999). Grazing and carnivorous invertebrates were virtually absent from our experimental units at each sampling date, thus preventing us from hypothesizing that analogous mechanisms were responsible for our results.

Several studies have indicated that the loss of algal canopies causes drastic changes in the species richness of associated assemblages, whose direction depends on complex interactions between abiotic and biological factors (reviewed by Airoldi et al. 2008). For example, the removal of a canopy-forming species may increase the free space available for colonization by other species, thus increasing the total diversity of the system (Jenkins et al. 1999, 2004), while in other cases it can determine the opposite outcome through the dominance by a few opportunistic species, particularly under conditions of enhanced nutrient loads (Eriksson et al. 2006). In the present study, we did not find any interactive effects of experimental treatments on the 
total number of taxa (a proxy for species richness). This suggests that the responses of the studied assemblages likely depended on changes in patterns of abundance of individual taxa, i.e. on the identity of organisms exposed to experimental treatments, rather than absolute richness ( $\mathrm{O}^{\prime}$ Connor \& Crowe 2005, Cardinale et al. 2006, Stachowicz et al. 2007, Maggi et al. 2009). Our findings only indicated a consistently larger number of taxa in undisturbed than in disturbed patches, potentially suggesting that our experimental intensity of disturbance might be considered severe, although discrete, in terms of its effects on the diversity of the intertidal assemblages studied (sensu Connell 1978, Sousa 1979). Absolute differences of richness between undisturbed and disturbed assemblages, however, were small (about 1 taxon, on average); thus, the ecological relevance of the significant effect detected by the analysis should be interpreted with caution. This could simply be due to the large proportion of the total number of taxa represented by 1 taxon (respectively, $16.7 \%$ and $9 \%$ of mean values between 6 and 11 , in different treatments).

This study indicated that algal canopies may increase the resistance of intertidal assemblages to physical disturbance, adding to the evidence that this functional trait of assemblages may be drastically affected by the loss of habitat-forming species (Kennelly 1987, Kiirikki 1996, Bertness et al. 1999, Eriksson et al. 2007, Gamfeldt et al. 2008). Moreover, it suggests that multiple stressors operating simultaneously may interactively affect the structure of intertidal assemblages. Such complex effects cannot be inferred from studies on single disturbances (Paine et al. 1998, Darling \& Côté 2008). Therefore, our findings have important implications for predicting the responses of organisms to combined factors responsible for the global erosion of coastal biodiversity (Elmqvist et al. 2003, Bellwood et al. 2004, Micheli \& Halpern 2005), adding to the evidence that canopy-forming species cannot be replaced by functional equivalents once lost (Schiel 2006, Airoldi et al. 2009). Although further research is needed to evaluate the effects of different types of multiple stressors and their generality across a range of spatial and temporal scales and under sets of abiotic and biological circumstances larger than those examined here (Solan et al. 2004, Naeem 2008), this study will improve our ability to understand and predict the consequences of biodiversity loss due to concomitant human-related factors, including climate change and urbanization, and to implement conservation and management actions aimed at preserving the functioning of marine systems.

Acknowledgements. This research was carried out in the framework of the Responsive Mode Project BIOFUSE undertaken within the MarBEF Network of Excellence, funded by the EU's Sixth Framework Programme (contract no. GOCECT-2003-505446). This is contribution number MPS-09044 of MarBEF. I.B. is currently supported by a contract from Fundação para a Ciência e a Tecnologia (FCT, Ministério da Ciência, Tecnologia e Ensino Superior) within the Programa Ciência 2008 - Fundo Social Europeu. This study benefited from discussions within the BIOFUSE team lead by T. Crowe and L. Benedetti-Cecchi. F. Tuya and 3 anonymous reviewers provided valuable comments on the manuscript.

\section{LITERATURE CITED}

Airoldi L, Beck MW (2007) Loss, status and trends for coastal marine habitats of Europe. Oceanogr Mar Biol Annu Rev 45:345-405

Airoldi L, Rindi F, Cinelli F (1995) Structure, seasonal dynamics and reproductive phenology of a filamentous turf assemblage on a sediment influenced, rocky subtidal shore. Bot Mar 38:227-237

Airoldi L, Balata D, Beck MW (2008) The Gray Zone: relationships between habitat loss and marine diversity and their applications in conservation. J Exp Mar Biol Ecol 366:8-15

Airoldi L, Connell SD, Beck MW (2009) The loss of natural habitats and the addition of artificial substrata. In: Wahl M (ed) Marine hard bottom communities. Springer-Verlag, Berlin, Heidelberg, p 269-280

Allison G (2004) The influence of species diversity and stress intensity on community resistance and resilience. Ecol Monogr 74:117-134

Anderson MJ (2001) A new method for non-parametric multivariate analysis of variance. Austral Ecol 26:32-46

Anderson MJ (2003) PCO: a FORTRAN computer program for principal coordinate analysis. Department of Statistics, University of Auckland

Andrew NL, Mapstone BD (1987) Sampling and the description of spatial pattern in marine ecology. Oceanogr Mar Biol Annu Rev 25:39-90

Araújo R, Bárbara I, Sousa-Pinto I, Quintino V (2005) Spatial variability of intertidal rocky shore assemblages in the northwest coast of Portugal. Estuar Coast Shelf Sci 64: 658-670

Araújo R, Vaselli S, Almeida M, Serrão E, Sousa-Pinto I (2009a) Effects of disturbance on marginal populations: human trampling on Ascophyllum nodosum assemblages at its southern distribution limit. Mar Ecol Prog Ser 378: $81-92$

> Araújo R, Bárbara I, Tibaldo M, Berecibar E, Díaz Tapia P, Pereira R, Santos R, Sousa-Pinto I (2009b) Checklist of benthic marine algae and cyanobacteria of northern Portugal. Bot Mar 52:24-46

Bacchiocchi F, Airoldi L (2003) Distribution and dynamics of epibiota on hard structures for coastal protection. Estuar Coast Shelf Sci 56:1157-1166

Bellwood DR, Hughes TP, Folke C, Nystrom M (2004) Confronting the coral reef crisis. Nature 429:827-833

> Benedetti-Cecchi L (2001) Variability in abundance of algae and invertebrates at different spatial scales on rocky sea shores. Mar Ecol Prog Ser 215:79-92

Benedetti-Cecchi L, Cinelli F (1992) Canopy removal experiments in Cystoseira-dominated rockpools from the Western coast of the Mediterranean (Ligurian Sea). J Exp Mar Biol Ecol 155:69-83

Benedetti-Cecchi L, Cinelli F (1994) Recovery of patches in an assemblage of geniculate coralline algae: variability at different successional stages. J Exp Mar Biol Ecol 110:9-18 Benedetti-Cecchi L, Pannacciulli F, Bulleri F, Moschella PS, 
Airoldi L, Relini G, Cinelli F (2001) Predicting the consequences of anthropogenic disturbance: large-scale effects of loss of canopy algae on rocky shores. Mar Ecol Prog Ser 214:137-150

Bertness MD, Leonard GH (1997) The role of positive interactions in communities: lessons from intertidal habitats. Ecology 78:1976-1989

Bertness MD, Leonard GH, Levine JM, Schmidt PR, Ingraham AO (1999) Testing the relative contribution of positive and negative interactions in rocky intertidal communities. Ecology 80:2711-2726

Boyer KE, Kertesz JS, Bruno JF (2009) Biodiversity effects on productivity and stability of marine macroalgal communities: the role of environmental context. Oikos 118: 1062-1072

$>$ Boyra A, Nascimento FJA, Tuya F, Sanchez-Jerez P, Haroun RJ (2004) Impact of sea-cage fish farms on intertidal macrobenthic assemblages. J Mar Biol Assoc UK 84:665-668

Bray JR, Curtis JT (1957) An ordination of the upland forest communities of southern Wisconsin. Ecol Monogr 27: 325-349

Bulleri F, Airoldi L (2005) Artificial marine structures facilitate the spread of a non-indigenous marine alga, Codium fragile ssp. tomentosoides, in the north Adriatic Sea. J Appl Ecol 42:1063-1072

Bulleri F, Benedetti-Cecchi L, Acunto S, Cinelli F, Hawkins SJ (2002) The influence of canopy algae on vertical patterns of distribution of low-shore assemblages on rocky coasts in the northwest Mediterranean. J Exp Mar Biol Ecol 267: 89-106

Cardinale BJD, Srivastava S, Duffy JE, Wright JP, Downing AL, Sankaran M, Jouseau C (2006) Effects of biodiversity on the functioning of trophic groups and ecosystems. Nature 443:989-992

- Chapin FS, Sala OE, Burke IC, Grime JP and others (1998) Ecosystem consequences of changing biodiversity. Bioscience 48:45-52

Connell JH (1978) Diversity in tropical rain forests and coral reefs. Science 199:1302-1309

Connell SD (2003) The monopolization of understorey habitat by subtidal encrusting coralline algae: a test of the combined effects of canopy-mediated light and sedimentation. Mar Biol 142:1065-1071

> Connell SD, Russell BD, Turner DJ, Shepherd SA, Kildea T, Miller D, Airoldi L, Cheshire A (2008) Recovering a lost baseline: missing kelp forest from a metropolitan coast. Mar Ecol Prog Ser 360:63-73

> Costanza R, d'Arge R, de Groot R, Farber S and others (1997) The value of the world's ecosystem services and natural capital. Nature 387:253-260

Crain CM, Kroeker K, Halpern BS (2008) Interactive and cumulative effects of multiple human stressors in marine systems. Ecol Lett 11:1304-1315

Darling ES, Côté IM (2008) Quantifying the evidence for ecological synergies. Ecol Lett 11:1278-1286

Dayton PK (1975) Experimental evaluation of ecological dominance in a rocky intertidal algal community. Ecol Monogr 45:137-159

> Dethier MN, Graham ES, Cohen S, Tear LM (1993) Visual versus random-point percent cover estimations: 'objective' is not always better. Mar Ecol Prog Ser 96:93-100

$>$ Duggins DO, Eckman JE, Sewell AT (1990) Ecology of understory kelp environments II. Effects of kelp on recruitment of benthic invertebrates. J Exp Mar Biol Ecol 143:27-45

Easterling DR, Meehl GA, Parmesan C, Changnon SA, Karl TR, Mearns LO (2000) Climate extremes: observations, modeling, and impacts. Science 289:2068-2074
Elmqvist T, Folke C, Nyström M, Peterson G, Bengtsson J, Walker B, Norberg J (2003) Response diversity, ecosystem change, and resilience. Front Ecol Environ 1:488-494

> Emanuel KA (1987) The dependence of hurricane intensity on climate. Nature 326:483-485

Eriksson BK, Rubach A, Hillebrand H (2006) Biotic habitat complexity controls species diversity and nutrient effects on net biomass production. Ecology 87:246-254

Eriksson BK, Rubach A, Hillebrand H (2007) Dominance by a canopy forming seaweed modifies resource and consumer control of bloom-forming macroalgae. Oikos 116: 1211-1219

Folt CL, Chen CY, Moore MV, Burnaford J (1999) Synergism and antagonism among multiple stressors. Limnol Oceanogr 44:864-887

Fraschetti S, Terlizzi A, Benedetti-Cecchi L (2005) Patterns of distribution of marine assemblages from rocky shores: evidence of relevant scales of variation. Mar Ecol Prog Ser 296:13-29

> Gamfeldt L, Hillebrand H, Jonsson PR (2008) Multiple functions increase the importance of biodiversity for overall ecosystem functioning. Ecology 89:1223-1231

- Geider RJ, Delucia EH, Falkowsky PG, Finzi AC and others (2001) Primary productivity of planet earth: biological determinants and physical constraints in terrestrial and aquatic habitats. Glob Change Biol 7:849-882

Gower JC (1966) Some distance properties and latent root and vector methods used in multivariate analysis. Biometrika 53:325-338

Griffin JN, O'Gorman EJ, Emmerson MC, Jenkins SR, Klein AM, Loreau M, Symstad A (2009) Biodiversity and the stability of ecosystem functioning. In: Naeem S, Bunker DE, Hector A, Loreau M, Perrings C (eds) Biodiversity, ecosystem functioning, \& human wellbeing. Oxford University Press, Oxford, p 78-93

Halpern BS., Walbridge S, Selkoe KA, Kappel CV and others (2008) A global map of human impact on marine ecosystems. Science 319:948-952

Hooper DU, Vitousek PM (1997) The effects of plant composition and diversity on ecosystem processes. Science 277 : 1302-1305

Hooper DU, Chapin FS III, Ewell JJ, Hector A and others (2005) Effects of biodiversity on ecosystem functioning: a consensus of current knowledge. Ecol Monogr 75:3-35

> Hughes AR, Stachowicz JJ (2004) Genetic diversity enhances the resistance of a seagrass ecosystem to disturbance. Proc Natl Acad Sci USA 101:8998-9002

Ives AR, Carpenter SR (2007) Stability and diversity of ecosystems. Science 317:58-62

$>$ Jenkins SR, Hawkins SJ, Norton TA (1999) Direct and indirect effects of a macroalgal canopy and limpet grazing in structuring a sheltered inter-tidal community. Mar Ecol Prog Ser 188:81-92

Jenkins SR, Norton TA, Hawkins SJ (2004) Long term effects of Ascophyllum nodosum canopy removal on mid shore community structure. J Mar Biol Assoc UK 84:327-329

> Jones CG, Lawton JH, Shachak M (1994) Organisms as ecosystem engineers. Oikos 69:373-386

Kennelly SJ (1987) Inhibition of kelp recruitment by turfing algae and consequences for an Australian kelp community. J Exp Mar Biol Ecol 112:49-60

Kiirikki M (1996) Experimental evidence that Fucus vesiculosus (Phaeophyta) controls filamentous algae by means of the whiplash effect. Eur J Phycol 31:61-66

Legendre P, Anderson MJ (1999) Distance-based redundancy analysis: testing multispecies responses in multifactorial ecological experiments. Ecol Monogr 69:1-24 
Lilley SA, Schiel DR (2006) Community effects following the deletion of a habitat-forming alga from rocky marine shores. Oecologia 148:672-681

Loreau M, Naeem S, Inchausti P (2002) Biodiversity and ecosystem functioning: synthesis and perspectives. Oxford University Press, New York, NY

> Maggi E, Bertocci I, Vaselli S, Benedetti-Cecchi L (2009) Effects of changes in number, identity and abundance of habitat-forming species on assemblages of rocky shores. Mar Ecol Prog Ser 381:39-49

Mangialajo L, Chiantore M, Cattaneo-Vietti R (2008) Loss of fucoid algae along a gradient of urbanisation, and structure of benthic assemblages. Mar Ecol Prog Ser 358:63-74

McArdle BH, Anderson MJ (2001) Fitting multivariate models to community data: a comment on distance-based redundancy analysis. Ecology 82:290-297

McCann KS (2000) The diversity-stability debate. Nature 405:228-233

McCook LJ, Chapman ARO (1991) Community succession following massive ice-scour on an exposed rocky shore: effects of Fucus canopy algae and of mussels during late succession. J Exp Mar Biol Ecol 154:137-169

> Melville AJ, Connell SD (2001) Experimental effects of kelp canopies on subtidal coralline algae. Austral Ecol 26: 102-108

Menge BA (1997) Detection of direct versus indirect effects: Were experiments long enough? Am Nat 149:801-823

Micheli F, Halpern BS (2005) Low functional redundancy in coastal marine assemblages. Ecol Lett 8:391-400

> Michener WK, Blood ER, Bildstein KL, Brinson MM, Gardner LR (1997) Climate change, hurricanes and tropical storms, and rising sea level in coastal wetlands. Ecol Appl 7: $770-801$

Naeem S (2008) Advancing realism in biodiversity research. Trends Ecol Evol 23:414-416

O'Connor NE, Crowe TP (2005) Biodiversity and ecosystem functioning: distinguishing between effects of the number of species and their identities. Ecology 86:1783-1796

Paine RT, Tegner MJ, Johnson EA (1998) Compounded perturbations yield ecological surprises. Ecosystems 1: $535-545$

Pimm SL (1984) The complexity and stability of ecosystems. Nature 307:321-326

Ramage DL, Schiel DR (1999) Patch dynamics and response to disturbance of the seagrass Zostera novazelandica on intertidal platforms in southern New Zealand. Mar Ecol Prog Ser 189:275-288

Raper SCB (1993) Observational data on the relationship between climatic change and the frequency and magnitude of severe tropical storms. In: Warrick MA, Barrow EM, Wigley TML (eds) Climate and sea level change: observations, projections, and implications. Cambridge University Press, Cambridge, p 192-212

Reed DC, Foster MS (1984) The effects of canopy shading on algal recruitment and growth in a giant kelp forest. Ecology 65:937-948

Reusch TBH, Ehlers A, Haemmerli A, Worm B (2005) Ecosystem recovery after climatic extremes enhanced by genotypic diversity. Proc Natl Acad Sci USA 102:2826-2831

Schiel DR (2006) Rivets or bolts? When single species count in the function of temperate reef communities. J Exp Mar Biol Ecol 338:233-252

Schiel DR, Lilley SA (2007) Gradients of disturbance to an algal canopy and the modification of an intertidal community. Mar Ecol Prog Ser 339:1-11

Schiel DR, Taylor DI (1999) Effects of trampling on a rocky

Editorial responsibility: Laura Airoldi,

Ravenna, Italy intertidal algal assemblage in southern New Zealand. J Exp Mar Biol Ecol 235:213-235

Schiel DR, Wood SA, Dunmore RA, Taylor DI (2006) Sediment on rocky intertidal reefs: effects on early post-settlement stages of habitat-forming seaweeds. J Exp Mar Biol Ecol 331:158-172

Schwartz MW, Brigham CA, Hoeksema JD, Lyons KG, Mills MH, van Mantgem PJ (2000) Linking biodiversity to ecosystem function: implication for conservation biology. Oecologia 122:297-305

Seed R (1996) Patterns of biodiversity in the macro-invertebrate fauna associated with mussel patches on rocky shores. J Mar Biol Assoc UK 76:203-210

> Smith MD, Knapp AK (2003) Dominant species maintain ecosystem function with non-random species loss. Ecol Lett 6:509-517

Solan M, Cardinale BJ, Downing AL, Engelhardt KAM, Ruesink JL, Srivastava DS (2004) Extinction and ecosystem function in the marine benthos. Science 306: $1177-1180$

> Sousa WP (1979) Disturbance in marine intertidal boulder fields: the nonequilibrium maintenance of species diversity. Ecology 60:1225-1239

Stachowicz JJ, Bruno JF, Duffy JE (2007) Understanding the effects of marine biodiversity on communities and ecosystems. Annu Rev Ecol Syst 38:739-766

> Strong DR (1997) Quick indirect interactions in intertidal food webs. Trends Ecol Evol 12:173-174

Thompson RC, Crowe TP, Hawkins SJ (2002) Effects of long term environmental change on rocky intertidal communities. Environ Conserv 29:168-191

Tilman D (1999) The ecological consequences of changes in biodiversity: a search for general principles. Ecology 80: 1455-1474

Tuya F, Haroun RJ (2006) Spatial patterns and response to wave exposure of shallow water algal assemblages across the Canarian Archipelago: a multi-scaled approach. Mar Ecol Prog Ser 311:15-28

Underwood AJ (1997) Experiments in ecology. Their logical design and interpretation using analysis of variance. Cambridge University Press, Cambridge

Underwood AJ (1998) Grazing and disturbance: an experimental analysis of patchiness in recovery from a severe storm by the intertidal alga Hormosira banksii on rocky shores in New South Wales. J Exp Mar Biol Ecol 231: 291-306

> Underwood AJ (1999) Physical disturbances and their direct effect on an indirect effect: responses of an intertidal assemblage to a severe storm. J Exp Mar Biol Ecol 232: $125-140$

> van Ruijven J, Berendse F (2010) Diversity enhances community recovery, but not resistance, after drought. J Ecol 98: 81-86

Vaselli S, Bulleri F, Benedetti-Cecchi L (2008) Hard coastaldefence structures as habitats for native and exotic rockybottom species. Mar Environ Res 66:395-403

- Viejo RM, Arenas F, Fernández C, Gómez M (2008) Mechanisms of succession along the emersion gradient in intertidal rocky shore assemblages. Oikos 117:376-389

> Vitousek PM (1994) Beyond global warming: ecology and global change. Ecology 75:1861-1876

> Williams SL (2001) Reduced genetic diversity in eelgrass transplantations affects both population growth and individual fitness. Ecol Appl 11:1472-1488

> Worm B, Barbier EB, Beaumont N, Duffy JE and others (2006) Impacts of biodiversity loss on ocean ecosystem services. Science 314:787-790

Submitted: February 13, 2010; Accepted: July 9, 2010

Proofs received from author(s): August 27, 2010 